\title{
Motivasi Kerja Pada Perempuan Bali Yang Sudah Menikah \\ Dalam Perspektif Work-Life Balance
}

\author{
Ni Wayan Sinthia Widiastuti ${ }^{(1)}$ \\ IGN Putra Suryanata ${ }^{(2)}$ \\ Universitas Pendidikan Nasional ${ }^{(1)}$ \\ Universitas Pendidikan Nasional ${ }^{(2)}$ \\ sinthia.widiastuti@gmail.com ${ }^{(1)}$ \\ ngurahputrasuryanata@undiknas.ac.id ${ }^{(2)}$
}

\begin{abstract}
Women who have married initially only played a role in the domestic sector, which is focused on the nature of women biologically, namely taking care of the household. Current development through the influence of globalization and meeting the need to encourage women to play a role in the public sector. Especially in Bali, which is very thick with their culture tradition when a woman takes on the role as a breadwinner, as a housewife, and active in society, so that Balinese women play three roles. The purpose of the research is to explain the work motivation of Balinese women who work in a work-life balance perspective. This study used a qualitative method with a phenomenological approach. The sampling technique used was purposive sampling technique. Informants in this study consisted of seven people including four people working in the informal sector and three people working in the formal sector, with the criteria of women, ethnic Balinese, Hindus, married, having children, working. The technique of data collection is done by semi-structured interviews. This research shows a picture of married Balinese women in maintaining balance or often referred to as work-life balance and encouragement that makes Balinese women decide to work, even though they know many roles that are carried out.
\end{abstract}

Keywords : married balinese women; work motivation; work-life balance 
Perempuan yang sudah menikah pada awalnya hanya berperan pada sektor domestik yaitu menitik beratkan pada kodrat perempuan secara biologis yaitu mengurus rumah tangga. Perkembangan zaman dan pengaruh globalisasi serta pemenuhan kebutuhan mendorong perempuan untuk berperan pada sektor publik. Khususnya di Bali, yang kental akan adat dan istiadatnya ketika seorang perempuan mengambil peran sebagai pencari nafkah, sebagai ibu rumah tangga, dan bermasyarakat sehingga perempuan Bali menjalankan tiga peran. Tujuan penelitian mengetahui motivasi kerja perempuan Bali yang bekerja dalam perspektif work-life balance. Penelitian ini menggunakan metode kualitatif dengan pendekatan fenomenologi. Teknik sampling yang digunakan adalah dengan teknik purposive sampling. Informan dalam penelitian ini terdiri dari tujuh orang diantaranya empat orang bekerja pada sektor informal dan tiga orang bekerja pada sektor formal, dengan kriteria perempuan, suku Bali, beragama hindu, sudah menikah, memiliki anak, bekerja. Teknik pengumpulan data dilakukan dengan wawancara semi terstruktur. Penelitian ini menghasilkan gambaran perempuan Bali yang sudah menikah dalam menjaga keseimbangan atau yang sering disebut dengan istilah work-life balance serta dorongan yang membuat perempuan Bali memutuskan untuk bekerja, meski mengetahui banyak peran yang dijalankan.

Kata kunci : perempuan bali yang sudah menikah; motivasi kerja; dan work-life balance 


\section{PENDAHULUAN}

Keterlibatan perempuan dalam dunia kerja guna memberikan pemerataan terhadap proses pembangunan merupakan suatu keharusan, walaupun masih terjadi diskriminasi. Adanya gerakan-gerakan serta kajian-kajian perempuan, memberikan kesempatan bagi perempuan untuk bisa tampil di dunia yang secara tradisional dianggap dunia pria (Darma, 2019).

Pada beberapa tahun terakhir ini, keterlibatan wanita pada sektor publik menunjukkan angka yang terus meningkat. Hal ini menunjukkan bahwa motivasi wanita untuk bekerja di sektor publik semakin tinggi. Beberapa faktor yang melatar belakangi mengapa terjadi peningkatan tersebut antara lain : tingkat pendidikan yang dimiliki, desakan ekonomi keluarga, waktu luang yang dimiliki wanita. Keperluan akan peningkatan ekonomi rumah tangga merupakan salah satu alasan utama para wanita meninggalkan peran mereka hanya sebagai ibu rumah tangga dan masuk ke pasar kerja (Rahaju, et.al., 2012).

Saat ini fenomena wanita bekerja bukan hal yang aneh lagi di kalangan masyarakat. Selain untuk memenuhi kebutuhan, bekerja merupakan salah satu cara untuk mengembangkan kemampuan serta potensi yang dimiliki. Wanita zaman sekarang dapat melakukan pekerjaan yang dilakukan oleh kaum pria. Bahkan rakyat Indonesia pernah dipimpin oleh presiden wanita yang diberi kesempatan besar untuk berkiprah di dunia kerja. Kedudukan wanita saat ini tidak kalah pentingnya dengan pria. Bahkan saat ini dalam lingkup masyarakat, seorang ibu rumah tangga tidak hanya berperan dalam mengurus kebutuhan keluarga saja, melainkan menjalankan peran ganda yakni bekerja. Fenomena yang terjadi dalam masyarakat adalah semakin banyaknya perempuan membantu suami mencari tambahan penghasilan (Darma, 2018).

Perempuan pada awalnya hanya berperan pada sektor domestik yaitu menitik beratkan pada kodrat perempuan secara biologis. Contohnya peran sebagai ibu, seperti mengandung, melahirkan dan menyusui anak adalah kodrat dari seorang ibu. Peran ini pada akhiranya diikuti dengan mengerjakan kewajiban mengerjakan pekerjaan rumah. Serta adanya anggapan sebagian masyarakat, bahwa perempuan hanya sebagai pembantu dan pengatur bukan sebagai salah satu pemimpin di dalam rumah tangga, yang fungsinya sebagai pendukung suami, yang bertugas untuk memperhatikan suami (Sukri, Suhandjati dan Sofwan, 2001).

Perkembangan zaman dan pengaruh globalisasi mendorong perempuan untuk bekerja. Menurut Dewi (2016) menyatakan bahwa faktor ekonomi juga merupakan hal yang memotivasi perempuan untuk mencari nafkah. Banyaknya perempuan yang terjun ke dunia kerja juga tidak terlepas karena adanya peluang yang diberikan perusahaan bagi para perempuan untuk bekerja. 
Hal ini sejalan dengan Tjaja (2000) yang menyatakan dorongan untuk bekerja juga muncul karena adanya ekspektasi ekonomi berupa peningkatan pendapatan yang diperoleh melalui bekerja. Dengan terjunnya perempuan sebagai pencari nafkah, tentu saja hal ini menambah peran yang dijalankan oleh perempuan.

Upaya atau kekuatan baik dari dalam maupun dari luar diri yang mendorong seseorang untuk mencapai tujuan tertentu yang telah ditetapkan sebelumnya disebut dengan istilah motivasi kerja Semakin tinggi seseorang memiliki motivasi maka dapat terlihat pada intensitasnya dalam perilaku tertentu. Selain itu orang yang memiliki motivasi tinggi juga menunjukkan adanya persistence yang kuat. Persistence ini dijelaskan sebagai perilaku yang memiliki keterlibatan yang berkelanjutan dalam pencapaian tujuan (Nindyati, 2015).

Provinsi Bali sebagai salah satu Provinsi di Indonesia tidak terlepas dari arus perubahan ini (Nayaka dan Darma, 2020). Bali merupakan salah satu provinsi di Indonesia yang terkenal akan adat istiadat dan keunikan budayanya (Juzer dan Darma, 2019). Budaya yang kental biasanya akan lebih banyak memerlukan peran dari anggota kebudayaan tersebut yang dikenal sebagai bagian dari peran sosial (Matsumoto, 2008). Masyarakat Bali memiliki berbagai macam budaya yang berkembang dengan agama Hindu yang menjiwainya. Budaya Hindu Bali membuat masyarakat Bali mempunyai tugas dan tanggung jawab yang sangat kompleks khususnya perempuan Bali, karena perempuan Bali tidak hanya memiliki peran domestik dan ekonomi tetapi juga peran bermasyarakat yaitu terlibat dalam tugas-tugas adat yang merupakan ciri khas peran kehidupan perempuan Bali (Nainggolan dan Darma, 2018).

Dalam kaitan dengan perempuan Bali yang bekerja publik (bekerja mencar nafkah), bekerja dari segi ekonomi walaupun bisa juga karena aktualisasi diri, yang jelas mereka pasti berusaha bekerja dengan baik, pintar, dan cerdas dalam mengatur waktu, disiplin, dan mencintai pekerjaannya. Namun, di sisi lain adanya kewajiban-kewajban non ekonomi (adat, agama, dan rumah tangga), yang sering membatasi keterlibatan perempuan Bali di sektor publik. Keadaan seperti ini terutama kegiatan adat dalam budaya Bali, yang merupakan kewajiban bagi setiap warga dapat menghambat aktivitas perempuan dilingkungan kerjanya.

Adanya banyak peran yang dijalankan oleh perempuan Bali, hal ini tentu saja menyebabkan perempuan Bali mengalami kelelahan yang mereka terkadang tidak menjalankan peran rumah tangga dan pekerjaan dengan baik. Hal ini sejalan dengan yang dikemukakan oleh Friedman, Christensen, \& DeGroot (1998) bahwa sulitnya memenuhi keseimbangan antara kehidupan pekerjaan dan kehidupan pribadi atau yang sering disebut dengan istilah work-life balance. Meskipun banyaknya peran yang dimiliki perempuan Bali, namun perempuan Bali tetap untuk memutuskan bekerja. 
Berdasarkan pemaparan tersebut tersebut, dapat dilihat bahwa perempuan Bali memiliki kompleksitas peran kehidupan yang dijalankan dikarenakan pekerjaan serta adanya pengaruh budaya yang melatarbelakangi. Sehingga dalam hal ini penting untuk mengetahui bagaimana perempuan Bali dalam menjaga keseimbangan antara kehidupan kerja dan kehidupan diluar pekerjaan atau yang sering disebut dengan istilah work-life balance serta dorongan yang membuat perempuan Bali memutuskan untuk bekerja atau yang dikenal dengan istilah motivasi kerja, meski mengetahui banyak peran yang dijalankan.

\section{Motivasi}

Motivasi adalah suatu proses pemenuhan kebutuhan sehingga mendorong seseorang untuk melakukan sesuatu kegiatan yang mengarah untuk pencapaian tujuan tertentu (Munandar, 2008; Widiatmika dan Darma, 2018). Steers \& Porter (dalam Riggio, 2009) mengemukakan motivasi adalah kekuatan yang melayani tiga fungsi; fungsi untuk memberikan energi, atau menyebabkan orang untuk bertindak; mengarahkan perilaku ke arah pencapaian tujuan tertentu; dan menopang usaha yang dikeluarkan dalam mencapai tujuan tersebut. Motivasi secara umum juga sering diartikan sebagai sesuatu yang ada pada diri seseorang yang dapat mendorong, mengaktifkan, menggerakkan dan mengarahkan perilaku seseorang, dengan kata lain, motivasi itu ada dalam diri seseorang dalam wujud niat, harapan, keinginan, dan tujuan yang ingin dicapai (Herniyani, 2012). Definisi mengenai motivasi kerja selanjutnya diungkapkan oleh Hasibuan (2000). Menurut Hasibuan (2000) motivasi kerja merupakan pemberian daya penggerak yang menciptakan kegairahan seseorang, agar mau bekerja sama, bekerja efektif dan terintegrasi dengan segala daya upayanya untuk mencapai tujuan.

\section{Work-life balance}

Clutterbuck (2003) menyatakan bahwa balance umumnya menyiratkan beberapa rasa keadilan atau kewajaran. Pada dunia kerja, workaholic dianggap tidak seimbang karena mereka tidak menyesuaikan diri dengan orang-orang yang diharapkan tentang di mana dan bagaimana mereka menginvestasikan waktu dan energi mereka. Definisi keseimbangan kerja dalam konteks work life balance adalah suatu keadaan di mana seseorang mengelola konflik nyata atau potensial antara berbagai demensi mengenai waktu dan energinya dengan cara memenuhi kebutuhan dirinya akan kesejahteraan dan pemenuhan diri sendiri. Kirchmeyer (2000) juga mendefinisikan kehidupan yang seimbang sebagai sejauh mana individu terlibat dan merasa puas terhadap peran kerja dan peran keluarga. Menurutnya bahwa untuk mencapai pengalaman 
yang memuaskan di semua domain kehidupan memerlukan sumber daya pribadi seperti energi, waktu, dan komitmen untuk didistribusikan dengan baik ke seluruh wilayah.

Adams (2006) mengemukakan bahwa work-life balance merupakan suatu kebutuhan untuk menyeimbangkan tuntutan kehidupan kerja dengan tuntutan kehidupan di luar pekerjaan sehingga dapat menjalani kehidupan yang memuaskan. Tercapainya work-life balance memungkinkan individu untuk terlibat dalam kegiatan yang secara intrinsik berharga bagi diri sendiri, merangkul banyak aspek kehidupan individu yang mencerminkan kesejahteraan dan kualitas hidup. Artinya individu mampu menggabungkan antara pekerjaan dengan merawat anggota keluarga, memiliki waktu untuk mengembangkan teman dan jaringan sosial (Hobson, 2014).

\section{Kerangka Konseptual}

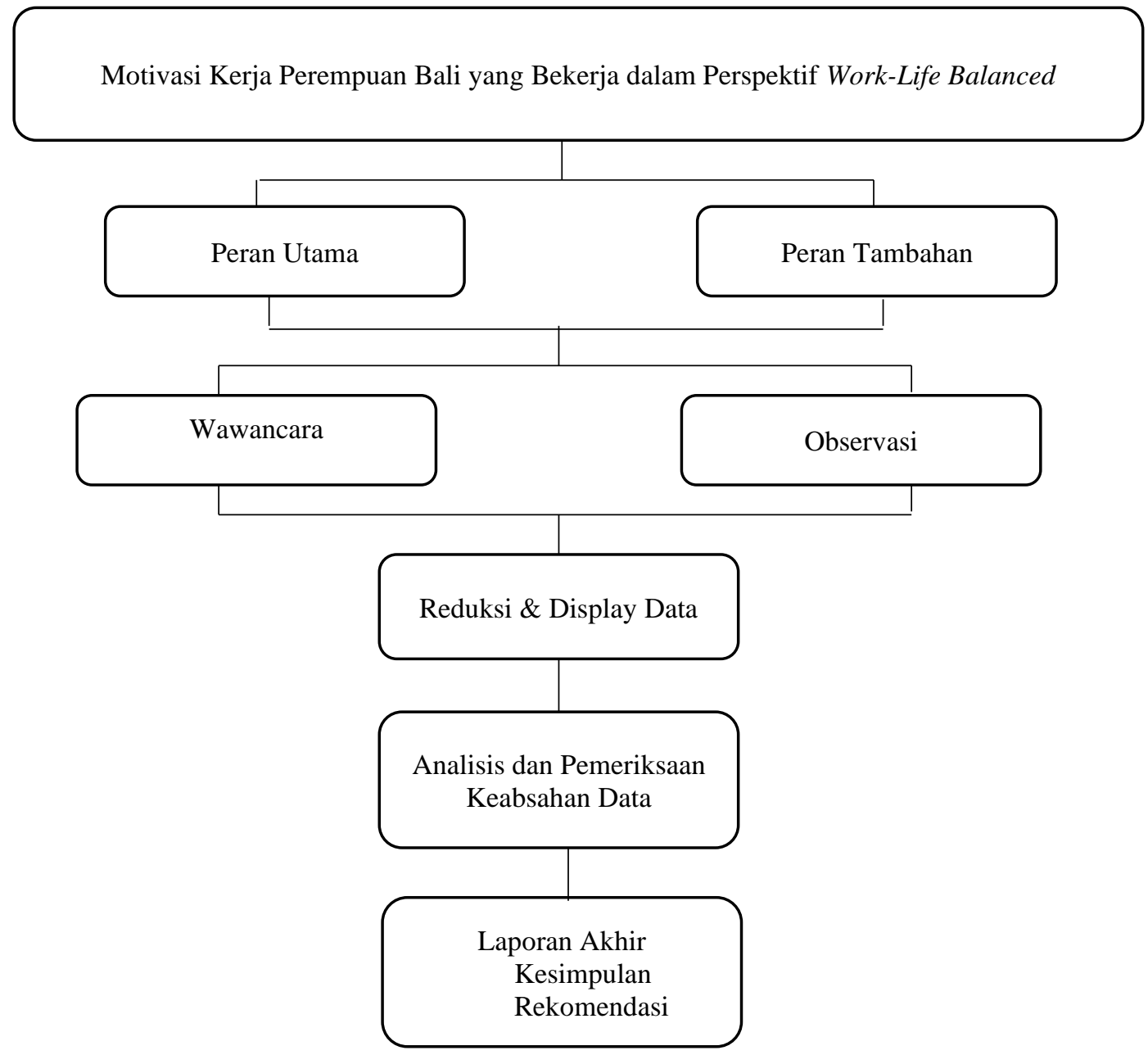

\section{METODE PENELITIAN}

Penelitian kualitatif adalah penelitian yang bermaksud untuk memahami fenomena tentang apa yang dialami oleh subjek penelitian misalnya perilaku, persepsi, dan motivasi 
(Moleong, 2014). Penelitian ini menggunakan pendekatan kualitatif untuk menggali informasi secara luas dan mendalam untuk mengetahui gambaran motivasi kerja perempuan bali dalam perspektif worklife balance dan menyelidiki pengalaman kesadaran masing-masing individu dengan segala kompleksitas dalam konteks sebagai perempuan Bali yang juga berperan sebagai pencari nafkah. Penelitian ini dilaksanakan di tempat berbeda sesuai dengan lokasi pengambilan data yang sedang dilakukan. Pengambilan data dengan teknik wawancara dan observasi dilakukan di tempat yang telah disepakati antara peneliti dan informan. Informan penelitian dipilih dengan menggunakan teknik purposive samping. Menurut Sugiyono (2014) purposive sampling adalah teknik pengambilan sampel sumber data dengan tertentu. Informan yang akan diwawancarai dan dianggap dapat memberikan informasi terkait dengan penelitian ini memiliki kriteria perempuan, suku Bali, beragama Hindu, sudah menikah, memiliki anak, bekerja.

\section{PEMBAHASAN}

Berdasarakan hasil wawancara terhadap ketujuh informan mengakui bahwa sebagai perempuan yang sudah menikah memiliki tanggung jawab terhadap diri sendiri, keluarga dan adat istiadat, mengurus suami dan anak, membantu mencari nafkah, beryadnya. Sedangkan sebagai perempuan Bali yaitu mebanten, menyame braya, ngayah ke pura. Jadi dapat disimpulkan bahwa sebagai perempuan Bali yang sudah menikah memiliki tiga peran yaitu, peran rumah tangga, peran ekonomi, dan peran adat. Hal ini sesuai dengan penelitian yang dilakukan oleh Tirtayani (2012) yang menytakan bahwa wanita Bali yang terikat pada adat tentunya dituntut lagi keseimbangan, karena harus menjalankan tiga peran (triple-roles) sekaligus, yakni pertama peran rumah tangga, kedua peran ekonomi, dan ketiga peran adat baik di keluarga, banjar maupun di desa adat.

Meskipun mengetahui peran yang dijalankan sebagai perempuan Bali yang sudah menikah, namun ada beberapa pendorong mengapa perempuan memasuki lapangan kerja, seperti tingkat pendidikan serta keterampilan yang dimiliki, desakan ekonomi keluarga, waktu luang yang dimiliki. Keperluan akan peningkatan ekonomi rumah tangga merupakan salah satu alasan utama para wanita meninggalkan peran mereka hanya sebagai ibu rumah tangga dan masuk ke pasar kerja (Rahaju, 2012).

McClelland mengembangkan konsep teori motivasi dengan menggunakan pedoman pemahaman tentang kebutuhan (needs) yang dikemukakan oleh Murray (dalam Hall \& Lindzey, 1993). Teori motivasi yang dikembangkan oleh McClelland dikenal sebagai teori tiga kebutuhan. Menurut McClelland kebutuhan individu meliputi tiga hal, yaitu need for 
achievement (kebutuhan untuk berprestasi), neef for power (kebutuhan untuk berkuasa), dan need for affiliation (kebutuhan untuk berhubungan dengan orang lain). Ketiga kebutuhan tersebut mempunyai kekuatan yang berbeda untuk mendorong munculnya perilaku pada setiap individu, dan perilaku yang diperlihatkan juga berbeda sesuai dengan dominasi kebutuhan yang ada pada setiap individu.

Untuk bisa memenuhi kebutuhan keluarga tersebut jika hanya mengandalkan satu sumber penghasilan saja, tentunya akan timbul banyak kesulitan. Rahaju, Mulyati, Sumarlan (2012) menyatakan bahwa sebagian perempuan yang sudah menikah memutuskan untuk ikut membantu perekonomian keluarga dengan ikut bekerja. Menurut Dewi (2016) menyatakan bahwa faktor ekonomi juga merupakan hal yang memotivasi perempuan untuk mencari nafkah. Hal ini sesuai dengan teori Steers dan Poters (dalam Mullins, 2010), individu bekerja karena faktor organisasional untuk mendapatkan gaji, yang mana dalam hal ini gaji yang dimaksudkan adalah untuk membantu perekonomian keluarga.

Selain itu berdasarkan wawancara dengan bu WS, bu KN dan bu WR, menyatakan bahwa bekerja adalah untuk bersosialisasi. Hal ini sesuai dengan Teori yang dipaparkan oleh McCelland yaitu need for affiliation. Yang mana individu termotivasi untuk bekerja yaitu memenuhi kebutuhan untuk berhubungan dengan orang lain. Tersedianya kesempatan bagi perempuan yang sudah menikah untuk bekerja seperti memiliki latar belakang pendidikan serta keterampilan yang dimiliki juga merupakan suatu dorongan bagi perempuan untuk bekerja.

Motivasi perempuan yang sudah menikah dalam bekerja tidaklah sama antara satu dengan yang lain. Hal ini dapat dilihat dari hasil wawancara terhadap ketujuh informan tersebut. Bagi perempuan, khususnya yang berstatus sudah menikah, bekerja dapat diartikan untuk membantu perekonomian keluarga. Selain itu juga kebutuhan akan berhubungan dengan orang lain, ingin mandiri agara tidak bergantung pada suami serta bekerja untuk mendapatkan tantangan baru.

Jumlah anggota keluarga sangat menentukan jumlah kebutuhan keluarga.Semakin banyak anggota keluarga berarti semakin banyak pula jumlah kebutuhan keluarga yang harus dipenuhi.Begitu pula sebaliknya, semakin sedikit anggota keluarga berarti semakin sedikit pula kebutuhan yang harus dipenuhi keluarga. Sehingga dalam keluarga yang jumlah anggotanya banyak, akan diikuti oleh banyaknya kebutuhan yang harus dipenuhi. Semakin besar ukuran rumahtangga berarti semakin banyak anggota rumahtangga yang pada akhirnya akan semakin berat beban rumahtangga untuk memenuhi kebutuhan sehari-harinya.

Jumlah tanggungan khususnya anak biasanya akan menjadi harapan bagi sebuah keluarga untuk dapat menyelamatkan mereka dari keterpurukan, hal itu berbasis pada istilah 
"banyak anak banyak rezeki”. Namun semakin banyak jumlah tanggungan yang dimiliki oleh sebuah keluarga biasanya akan berpengaruh pada tingkat pengeluaran keluarga tersebut. Bisa jadi jika makin banyak tanggungan maka alokasi dana masing-masing anak akan berkurang jika tidak dibarengi dengan pendapatan yang cukup. Selain itu jumlah tanggungan bisa menjadi alasan seseorang untuk bisa bekerja , misal saja seorang pekerja yang memiliki tanggungan akan lebih semangat karena dia sadar bahwa bukan hanya dia yang akan menikmati hasilnya tapi ada orang lain yang menunggu jerih payahnya dan menjadi tanggung jawabnya.

Berdasarkan hasil wawancara terhadap ketujuh informan mengakui bahwa sudah bekerja sebelum menikah. Tentu saja ada perbedaan ketika bekerja sebelum menikah dan sesudah menikah, karena ketika sudah menikah selain bekerja para perempuan ini harus mengurus anak dan suaminya. Keputusan untuk tetap bekerja meskipun telah mengetahui akan ada banyak peran yang dilakukan oleh perempuan Bali, hal ini tidak terlepas dari adanya dukungan dari suami. Adanya dukungan dari suami merupakan hal yang pnting bagi prempuan Bali yang sudah menikah. Hal ini sejalan dengan Adam (Kumolohadi, 2001) yang mengemukakan bahwa dukungan sosial dari suami adalah bantuan yang diberikan oleh suami. Beberapa ahli juga berpendapat bahwa dukungan sosial suami adalah dukungan atau bantuan dalam memberikan dorongan atau motivasi tersendiri pada istri yang berperan ganda yang biasanya ditunjukkan dalam bentuk perhatian, kesediaan mendengarkan keluh kesah dan setiap saat memberikan masukan-masukan yang sifatnya positif. Dengan demikian, beban istri menjadi berkurang dalam menghadapi konflik peran ganda dan kepuasan perkawinan pun akan meningkat karena adanya kebersamaan, pengertian dan toleransi. Berdasarkan hasil wawancara terhadap tujuh informan, menyatakan hal yang serupa terkait dengan adanya dukungan dari suami terkait dengan dorongan untuk bekerja sehingga dalam ketika bekerja bagi perempuan Bali yang sudah menikah tidak terlalu menjadi beban.

Selain adanya dukungan dari suami, ketika sesorang mengalami banyak peran, pengaturan waktu tidak kalah pentingnya. Dari hasil wawancara terhadap tujuh informan menyatakan bahwa tidak merasa keberatan dalam menjalani kehidupannya dengan berbagai peran, baik perannya sebagai ibu dan istri, sebagai pekerja serta bermasyarakat. Hal ini hanya terkait dengan masalah prioritas serta dalam mengatur waktu. Berdasarkan hasil wawancara, bagi perempuan Bali yang bekerja di sektor formal, lebih banyak menghabiskan waktu ditempat kerja. Hal ini tentu saja terkait dengan adanya aturan perusahaan, sehingga ketika ada kegiatan adat bisa dilakukan setelah pulang bekerja atau saat di jam-jam tertentu permisi dari kantor. Namun, ketika kegiatan ada tersebut sangat penting, maka perempuan Bali yang bekerja 
akan mengambil cuti. Dalam mengurus suami dan anak pun tetap dilakukan seperti ketika sebelum berangkat bekerja dan setelah pulang bekerja.

Berbeda dengan perempuan Bali yang bekerja di sektor informal, lebih banyak menghabiskan waktu dirumah untuk menjalankan peran domestiknya. Tentu saja hal ini disebabkan karena pada sektor informal tidak ada aturan baku terkait dengan jam bekerja, sehingga ketika terdapat kegiatan adat perempuan Bali yang bekerja pada sektor informal dapat selalu berpartisipasi dalam kegiatan adat tersebut. Berdasarkan hasil wawancara dari tiga informan yang bekerja pada sektor informal lebih banyak mnghabiskan waktu di rumah dibandingkan dengan di tempat kerja. Ketika terdapat kegiatan adat ketiga informan mengaku tidak bekerja untuk ikut berpartisipasi dalam kegiatan adat tersebut. Hal ini disebabkan karena pada sektor informal tidak terikat pada perusahaan seperti sektor formal.

Dalam melakukan banyak peran, sejauh mana seseorang melakukan perilaku dan tuntutan waktu baik pekerjaan yang dibayar, tanggung jawab pribadi, dan keluarga hal ini disebut dengan istilah work-life balance (Hill, Hawkins, Ferris, dan Weitzman, 2001).

Berdasarkan wawancara terhadap ketujuh informan mengaku bahwa masalah dikehidupan pribadinya tidak dibawa atau tidak memengaruhi pekerjaannya. Begitu pula sebaliknya. Jika dikaitkan dengan teori work interference with personal life (WIPL) yang mengacu pada sejauh mana pekerjaan dapat mengganggu kehidupan pribadi individu serta life interference with work (PLIW) yang mengacu pada sejauh mana kehidupan pribadi individu mengganggu kehidupan pekerjaannya, kedua hal tersebut tidak dialami oleh ketujuh informan. Menurut Heider (1958) bahwa setiap individu memiliki kecenderungan untuk menyeimbangkan relasi antara kehidupan pribadi dengan objek-objek pada lingkungan disekitarnya, bilamana ketidakseimbangan muncul maka individu akan termotivasi untuk mengembalikan relasi pada keadaan seimbang. Dalam hal ini ketujuh informan yang merupakan perempuan Bali yang sudah menikah, mencoba melakukan kesimbangan dalam menjalankan peran-peran yang dilakukannya sehingga tidak menjadi masalah dalam menjalankan banyak peran. Menurut Parkes dan Langford (2008), individu yang ingin mencapai work-life balance dalam menjalankan peran harus memiliki ikatan dengan menjaga keseimbangan tangung jawab pada pekerjaan, keluarga, diri sendiri serta dalam kehidupan sosial diluar keluarga dan pekerjaan.

\section{PENUTUP}

Berdasarkan dari hasil penelitian yang dilakukan dan hasil pembahasan diatas, maka dapat disimpulkan bahwa perempuan yang sudah menikah merasa bahwa peran mereka setelah 
menikah tidak hanya pada sektor domestik seperti mengurus rumah, mengurus anak dan suami, tetapi juga mencari nafkah. Peran sebagai perempuan Bali yaitu berbagai kegiatan antara lain menghadiri serta mengikuti kegiatan adat dan keagamaan seperti melaksanakan ayahan (kewajiban) di Pura (tempat suci agama Hindu) apabila ada upacara keagamaan.

Dorongan dari dalam diri untuk bekerja pada perempuan Bali yang sudah menikah tidak lepas dari adanya keinginan untuk memenuhi kebutuham anak serta membantu suami dari sisi ekonomi. Tersedianya kesempatan bagi perempuan yang sudah menikah untuk bekerja seperti memiliki latar belakang pendidikan, keterampilan yang dimiliki serta adanya dukungan dari suami juga merupakan suatu dorongan dari luar diri bagi perempuan untuk bekerja. Adapun perbedaan bekerja sebelum dan setelah menikah yaitu ketika sebelum menikah ketika akan berangkat bekerja hanya mengurus diri sendiri saja, sedangkan ketika sudah menikah harus mengurus anak dan suami terlebih dahulu sebelum berangkat bekerja.

Pada perempuan yang bekerja pada sektor informal lebih banyak menghabiskan waktunya di rumah, sedangkan pada perempuan yang bekerja pada sektor formal lebih banyak mengabiskan waktu di tempat kerja. Bagi perempuan Bali yang sudah menikah antara kehidupan pribadi, pekerjaan dan bermasyarakat dalam hal ini kegiatan adat merupakah hal yang sama pentingnya, sehingga dibutuhkan manajemen waktu yang baik. Pada perempuan yang bekerja pada sektor informal ketika ada kegiatan adat, dapat dengan leluasa datang pada kegiatan adat tersebut karena perempuan yang bekerja pada sektor informal dapat mengatur pekerjaannya sendiri. Berbeda dengan perempuan yang bekerja pada sektor formal yang diharus mengikuti aturan perusahaan. Sehingga perempuan yang bekerja pada sektor formal ini tetap datang pada kegiatan adat terebut, ketika pulang bekerja. Namun jika kegiatan adat tersebut merupakan kegiatan yang peting atau yang menyenglenggarakan kegiatan tersebut adalah kerabat dekat, perempuan yang bekerja pada sektor formal ini mengambil cuti agar tetap bisa berpartisipasi dalam kegiatan adat tersebut. Dalam menghabiskan waktu mengurus rumah tangga dan menghabiskan waktu dengan keluarga pada perempuan yang bekerja pada sektor infomal dapat mengerjakannya setiap hari. Sedangkan pada perempuan yang bekerja pada sektor formal lebih banyak menghabiskan waktu untuk mengurus rumah dan menghabisakan waktu dengan keluarga yaitu ketika libur pada hari sabtu atau minggu. 


\section{DAFTAR PUSTAKA}

Adams, M. (2006). Work-life balance a practical guide for teachers. London: David Fulton Publishers.

Clutterbuck, D. (2003). Managing work-life balance: a guide for HR in achieving organisational and individual change. London: Chartered Institute of Personnel and Development, CIPD House, Camp Road.

Darma, G.S. (2019). Kacamata Media, Kesuksesan Bersyarat. Indonesia: Pustaka Larasan Press.

Darma, G.S. (2018). Seuntai Pesan, Menjawab Zaman. Indonesia: Pustaka Larasan Press.

Dewi, C. K. (2016). Peran perempuan hindu: Antara reproduksi dan aktualisasi diri. In Perempuan \& kesuburan (pp. 3-13). Denpasar: Pustaka Ekspresi.

Friedman, S. D., Christensen, P., \& DeGroot, J. (1998). Work \& life: the end of the zero-sum game, Harvard Business Review, 76 (6): 119-129.

Herniyani, T. (2012). Modul pengantar manajemen. Sumatera Utara: Tri Guna Dharma.

Hill, E. J., Hawkins, A. J., Ferris, M., \& Weitzman, M. (2001). Finding an extra day a week: the positive influence of perceived job flexibility on work and family life balance [electronic version], Family Relations, 50 (1): 49-54.

Hobson, B. (2014). Worklife balance the agency \& capabilities gap. UK: Oxford University Press.

Juzer, J., and Darma, G.S. (2019). Strategic Supply Chain Management in the Era of Industry Revolution 4.0 : A Study of Textile Industry in Bali, Jurnal Manajemen Bisnis, 16 (3): $1-16$.

Kirchmeyer, C. (2000). Work-life initiatives: Greed or benevolence regarding worker's time. In. C. L. Cooper \& D. M. Rousseau (Eds.). West Sussex, UK: Wiley.

Malayu, Hasibuan. (2000). Manajemen Sumber Daya Manusia. Jakarta: Bumi Aksara.

Matsumoto, D. (2008). Pengantar Psikologi Lintas Budaya. Yogyakarta: PustakaBelajar.

Moleong, L. J. (2014). Metodologi Penelitian Kualitatif. Bandung: Remaja Rosdakarya.

Munandar, A. S.. (2008). Psikologi Industri dan Organisasi. Jakarta: Universitas Indonesia.

Nainggolan, R.H.., and Darma, G.S. (2018). Menguji Ketangkasan Manajemen dan Pengelolaan Keamanan di Pulau Bali, Jurnal Manajemen \& Bisnis, 15 (4): 92-108.

Rahaju, M. E., Mulyati, T., \& Sumarlan. (2012). Motivasi Wanita Bekerja dan Pengaruhnya Terhadap Kontribusi Pendapatan Keluarga, Ekomaks , I (2): 80-94. 
Nayaka, K. W., and Darma, G. S. (2020). Assessing Depth of Optimization Digital Samsat Program (E-Samsat) in Bali Province, International Research Journal of Engineering, IT \& Scientific Research, 6(2), 24-31. https://doi.org/10.21744/irjeis.v6n2.861

Nindyati, D. A. (2014). Pemaknaan Motivasi Kerja Kuat dan Motivasi Kerja Lemah (Studi Kasus Pada Dosen, Manajer dan Staf Laki-laki dan Perempuan), Academic Research Paramadina : 1190-1152.

Riggio, R.E. (2009). Introduction to industrial/organizational psychology fifth edition. United States of America: Pearson Prentice Hall.

Sugiyono. (2014 ). Metode penelitian kombinasi. Bandung: Alfabeta.

Widiatmika, P.H., and Darma, G.S. (2018). Good Corporate Governance, Job Motivation, Organization Culture Which Impact Company Financial Performance, Jurnal Manajemen \& Bisnis, 15 (3): 82-99. 